\title{
A társas helyzetben tapasztalt flow-élmény kapcsolata az élettel való elégedettséggel és a pszichológiai jólléttel, fiatal felnótteknél
}

\author{
MAGYARÓDI TÍMEA* - OLÁH ATTILA \\ ELTE Eötvös Loránd Tudományegyetem Pszichológiai Intézet, Budapest
}

(Beérkezett: 2019. május 15.; elfogadva: 2019. december 16.)

\begin{abstract}
Elméleti háttér: A flow a jóllét növelésének egyik eszköze is lehet, aktivitáselméletként a viselkedés pozitív következményeire, növekedéshez való hozzájárulására épít. Cél: A társas helyzetben tapasztalt áramlat-élmény összefüggéseit a jóllét különbözó dimenzióival - élettel való elégedettség és pszichológiai jóllét - ezidáig nem vizsgálták, holott a társas kapcsolatok jóllétet növelő szerepét több koncepció hangsúlyozza. Jelen kutatás célja ezen összefüggés igazolása. A társas flow gyakoriságát, intenzitását, valamint a flow szinkronizáció tényezőinek hatását vizsgáljuk. Módszerek: 1060 fő, 18 éven felüli vizsgálati személy, életkor: $M(\mathrm{SD})=26,67(10,76)$ év, vett részt az online kérdőíves módszerrel lebonyolított keresztmetszeti kutatásunkban. A kérdőíveket anonim módon töltötték ki: Általános Flow Leírás, Általános Flow Leírás Társas Interakciókban, Flow Állapot Kérdőív, Flow Szinkronizáció Kérdőív, Élettel Való Elégedettség Skála és Pszichológiai Jóllét Skálák. Eredmények: A hierarchikus lineáris regresszióanalízis alapján elmondható, hogy a társas helyzetben átélt flow-élmény gyakorisága $(\beta=0,07 ; p=0,038)$ és intenzitása $(\beta=0,08 ; p=$ $0,039)$ az élettel való elégedettség szignifikáns, kismértékú magyarázó tényezője. Az egyéni helyzetben átélt flow gyakorisága $(\beta=0,10 ; p=0,002)$ és a társas helyzetben tapasztalt optimális élményhez kapcsolódó szinkronizációs tényezők (az együttmúködő, flow-t indukáló helyzet interakciós jellemzői) $(\beta=0,15 ; p<0,001)$ szintén szignifikáns meghatározói a pszichológiai jóllétnek. Következtetések: Eredményeink alapján valószínúsíthető, hogy a flow-élmény társas helyzetben hozzájárul a jóllét különbözó aspektusaihoz, átélési gyakorisága, intenzitása, valamint az interakcióból fakadó szinkronizációs dimenziók támogatják a jóllét magasabb szintjének elérését.
\end{abstract}

Kulcsszavak: flow, flow szinkronizáció, társas, interakció, pszichológiai jóllét, élettel való elégedettség

\section{Bevezetés}

Az áramlat-élmény (flow) (Csikszentmihalyi, 1975) számos következménynyel járhat, affektív (rövid távon: hangulatváltozás; hosszú távon: hatás a jóllét különböző komponenseire), kognitív (kapacitás növekedése, feldolgo-

\footnotetext{
* Levelező szerzó: Dr. Magyaródi Tímea, ELTE Eötvös Loránd Tudományegyetem Pszichológiai Intézet, 1064 Budapest, Izabella u. 46. E-mail: magyarodi.timea@ppk.elte.hu
} 
zási stílusok fejlődése), fiziológiai és teljesítménybeli szempontból egyaránt (Keller \& Landhäußer, 2012). Kutatásunkban a pozitív pszichológia alapvető törekvéseinek (Seligman \& Csikszentmihalyi, 2000) eleget téve a jóllét és jól múködés feltételeként a flow-élmény társas helyzetben való átélésének disztális hatását kívánjuk ellenőrizni, amely az élmény minél gyakoribb és intenzívebb átélésének az aktuális állapothoz közvetlenül nem kapcsolódó következménye lehet. A jelenség társas interakcióban történő vizsgálatával reflektálunk a pozitív pszichológia kritikáira, miszerint szükséges a pozitív pszichológiai jelenségeket az individuális szinten túl is vizsgálni (Kashdan, Steger, \& Steger, Michael, 2011; Linley, Joseph, Harrington, \& Wood, 2006). Mivel a flow-élmény társas aspektusának vizsgálata kialakulóban lévő kutatási terület (Magyaródi \& Oláh, 2017), így indokolt a pozitív pszichológiai témakörök közé beemelni, és a jólléthez való hozzájárulását vizsgálni.

\subsection{Flow-élmény mint a jóllét növelésének eszköze}

A flow azt az állapotot jelöli, amikor a személy bevonódik egy kihívást jelentő aktivitásba. Az élmény a személy-környezet közötti dinamikus interakción múlik (Csikszentmihalyi, 1997), a tevékenység és a személy készségeinek folyamatos illesztéséról szól (Nakamura \& Csikszentmihalyi, 2002). Konceptuálisan a Csikszentmihalyi (1975) által leírt áramlat-élmény és a különböző jóllétfelfogások kapcsolatával eddig is számos tanulmány foglalkozott, mivel a flow akár a jóllét növelésének egyik eszköze is lehet (Lyubomirsky, 2008; Peterson, Park, \& Seligman, 2005).

Több különböző jóllétkoncepció ismert, amelyekkel a flow-elmélet szoros összefüggésbe hozható (Csikszentmihalyi, 1999). Mivel a flow következményeit mindeddig kevésbé tanulmányozták (Engeser \& Schiepe-Tiska, 2012), így jelen fejezetben a kutatási célkitűzéshez kapcsolódó élettel való elégedettség (Diener, Emmons, Larsen, \& Griffin, 1985) és pszichológiai jóllét (Ryff, 1989) elképzeléseit mutatjuk be.

A flow aktivitáselméletként a viselkedés következményeire, növekedéshez való hozzájárulására épít (Diener, 1984; Engeser \& Schiepe-Tiska, 2012). Sok esetben az áramlatcsatornából való kilépéskor, az éntudatosítás újbóli megjelenése után figyelhetók meg az élmény hangulatra, jóllétre vonatkozó pozitív hatásai (Carpentier, Mageau, \& Vallerand, 2012; Csikszentmihalyi, 1993; Fredrickson, 1998; Keller \& Landhäußer, 2012). Ilyenek lehetnek a pozitív érzelmek (Fredrickson, 1998), amelyek hosszú távon a kompetencia énhatékonyság, a megemelkedett teljesítmény megtapasztalásához kapcsolódóan akár a szubjektív jóllét meghatározó tényezői lehetnek (Diener, Lucas, \& Oishi, 2011), továbbá fontos kérdés a flow minél gyakoribb átélésétôl függő növekedésérzés, a pszichológiai jóllét hosszú távú támogatása is (Ryff, 1989). 
A kutatásban a jóllét és flow mértékének feltárásán túl arra vállalkozunk, hogy az áramlat társas aspektusának beemelésével megvizsgáljuk, hogy az a többlet, amely az egyéni helyzetben átélt flow-hoz képest társas együttmúködés során megjelenik (Magyaródi \& Oláh, 2017), kimutatható-e a jóllétre vonatkozó hatásokban is.

Hangsúlyozzuk, hogy a flow-élmény annak társas helyzetben való vizsgálatakor is szubjektív állapotot jelöl (Magyaródi \& Oláh, 2015b), az interakció sajátosságai feltételezhetően a szubjektív élmény minőségét támogatják, ezért jelen kutatásban a jóllét privát, személyes vonatkozásait vizsgáljuk (Keyes, 1998).

\subsection{A társas helyzetben átélt flow}

Több koncepció született az optimális-élmény társas helyzetben való megtapasztalásáról. Ezek alapvetően az élmény társas megtapasztalásának dinamikus jellemzőit emelik ki (Magyaródi \& Oláh, 2017): a specifikus vizsgálati, illetve hipotézisalkotáshoz szükséges kontextusokra, a kialakulás feltételeire, a személyek egymásra hatásának módjára, továbbá az élmény átfogó minőségére fókuszálnak, amely szerint a társas hatásnak hozzáadott értéke van az élményhez (Walker, 2010). Az áramlat szociális interakciókban való átélését alátámasztani kívánó elméletek - pl. érzelmi fertőzés (Hatfield, Cacioppo, \& Rapson, 1994), élmények/állapotok átterjedése (Westman, 2013), társas koordináció (Ackerman \& Bargh, 2010) - hangsúlyozzák az érzelmi, viselkedéses, pszichofiziológiai mintázatok automatikus szinkronizációját, valamint az interperszonális tapasztalat hozzáadott értékét. A partnerek közötti koordinációs tendencia elvezethet akár az egyes mentális állapotok (pl. kiégés, elköteleződés, élvezet, csúcsélmény) konvergenciájához is (Bakker, 2005). Ebből az összefüggésből indul ki a flow szinkronizáció koncepciója (Magyaródi \& Oláh, 2015b, 2016), amely a közös, kihívást jelentó tevékenységek közben létrejövő szubjektív flow-élmények egymásra hatását írja le, kiemelve az élménytöbblet jelentőségét, amely feltehetőleg az interakció sajátosságaiból fakad (Magyaródi \& Oláh, 2017).

Bár a flow-élmény társas szituációkban való átélésének jólléttel való kapcsolata egyelőre nem tisztázott, számos elképzelés kiemeli a szociabilitás (Harker \& Keltner, 2001) és társas támogatás (Lakey, 2013) jóllétre ható szerepét. Az élvezetes, új és izgalmas megosztott tevékenységekben való részvétel fokozza a pszichológiai jóllétet (Snyder \& Lopez, 2010), így feltételezésünk szerint a társas helyzetben tapasztalt flow-élmény, valamint az élményt támogató flow-szinkronizációs összetevők kapcsolódnak a jóllét különböző koncepcióihoz. 


\subsection{A szubjektív jóllét kognitív komponense: élettel való elégedettség}

A szubjektív jóllét (Diener, 1984) a személy saját jóllétének értékelése: érzelmi komponense a pozitív és negatív érzések optimális arányára vonatkozik (Fredrickson \& Losada, 2005), kognitív komponensét pedig az élettel való elégedettség jelenti, amikor a személy érzelmi vonatkozások nélkül megítéli, hogy mennyire elégedett az életével. Az élettel való elégedettség pozitív összefüggést mutat a flow-élménnyel (Fritz \& Avsec, 2007; Sahoo \& Sahu, 2009). Mivel az élettel való elégedettség kognitív múködést jelöl, ezért a flow élettel való elégedettséghez való hozzájárulásakor fontosak lehetnek a társas interakció által szolgáltatott plusz környezeti információk, a szituációkra való visszaemlékezés és értékelés szempontjából (Bryant \& Veroff, 2006; Echterhoff \& Hirst, 2009).

\subsection{Pszichológiai jóllét}

Egyes elképzelések szerint a jóllét több, mint a pozitív és negatív érzelmek optimális aránya (Keyes, 1998). A pszichológiai jóllét (Ryff, 1989) fogalma a boldogságkutatásokhoz szükséges elméletalkotás céljából került kifejlesztésre, és azon jellemzők összességeként fogható fel (Keyes, 2002), amelyek a személy pozitív pszichológiai múködéséhez vezetnek (önelfogadás, pozitív kapcsolat másokkal, autonómia, környezeti hatékonyság, életcél, személyes növekedés). A koncepció kidolgozása a korábbi, mentális egészségről alkotott elméletek, például Jahoda, Maslow munkái (Jahoda, 1958; Maslow, 1954), alapján valósult meg (Ryff \& Keyes, 1995).

Csikszentmihalyi (1990) érvelése szerint a flow-élmény a pszichológiai egészséghez vezethet, ezért feltételezzük, hogy az optimális-élmény a tanuláshoz és fejlődéshez kapcsolódó tényezői (Csikszentmihalyi, 1993) miatt hozzájárul a pszichológiai jóllét dimenzióhoz (Ryff, 1989).

Feltételezhető, hogy ahogyan az öndeterminációs elméletben (Ryan \& Deci, 2000) megjelenő humán alapszükségletek kielégülését célozza a flowélmény átélése az autonómia- és kompetenciaszükségletek támogatásával, úgy járul hozzá továbbá a személy-környezet interakció (Nakamura \& Csikszentmihalyi, 2002) útján a környezeti hatékonysághoz, az emergens motiváción keresztül - a tevékenység intrinzik motiválóvá válik, a motiváció fennmarad, pillanatról pillanatra épül és bontakozik ki a kihívások és készségek növekedésével (Mózes, Magyaródi, Soltész, Nagy, \& Oláh, 2012) - a személyes növekedéshez, az élmény átélése társas helyzetben pedig a másokkal való pozitív kapcsolatot eredményezheti (Graham, 2008). 
Ryff (1989) a pszichológiai jóllét fontos feltételeként említi a másokhoz való jó viszonyt, amit az érzelmi kötődések mellett a társas együttmúködésben végzett tevékenységeket követő sikerélmények is erősítenek.

\section{Hipotézisek}

Csikszentmihalyi (2009) kimondja, hogy hosszú távon nem az anyagi javak teszik boldoggá az embert, hanem a kihívások keresése és a készségek fejlesztése, valamint a hétköznapi élmények során tapasztalt együttmúködés mértéke. A flow-élmény társas helyzetben való múködéséről szóló koncepciók kiemelik az együttmúködés jelentőségét, így feltételezhető, hogy az egyéni helyzetben átélt flow-élmény mellett annak társas átélése is hozzájárul a magasabb jólléthez.

Mindezek alapján jelen kérdőíves vizsgálat hipotézisei a következők:

1. A flow-élmény és szubjektív jóllét összefüggéseinek (Collins, Sarkisian, \& Winner, 2009; Sahoo \& Sahu, 2009) kiegészítéseként feltételezzük, hogy

a) a társas helyzetben átélt áramlat-élmény gyakorisága magyarázza az élettel való elégedettség mértékét;

b) a társas helyzetben átélt áramlat-élmény intenzitása magyarázza az élettel való elégedettség mértékét.

2. A szakirodalomban hangsúlyozzák a pszichológiai jóllét és az optimális-élmény összefüggésére vonatkozó kutatási eredmények hiányát, mivel konceptuálisan feltételezhető a két jelenség közötti kapcsolat (Chen, Wigand, \& Nilan, 2000; Keyes, 2002), ezért feltételezzük:

a) a társas flow-élmény gyakorisága előrejelzi a pszichológiai jóllét mértékét;

b) a társas flow-élmény intenzitása és a partnerek között észlelt flowszinkronizáció mértéke előrejelzi a pszichológiai jóllét kimunkáltságát.

\section{Módszer}

\subsection{Minta}

1060 felnőtt vizsgálati személy vett részt a keresztmetszeti kutatásban, átlagéletkoruk 26,67 év volt ( $S D=10,76$ év). További jellemzőiket az 1. táblázat ismerteti. A részvétel önkéntes alapú, anonim volt, a hozzáférés a mintához kényelmi és hólabda módszerrel történt. 
1. táblázat. A minta $(n=1060)$ demográfiai jellemzői

\begin{tabular}{|l|l|c|}
\hline \multicolumn{2}{|c|}{ Változók } & Minta (\%) \\
\hline \multirow{4}{*}{ Nem } & Férfi & 34,6 \\
\cline { 2 - 3 } & Nó & 65,4 \\
\hline \multirow{4}{*}{ Lakóhely } & Budapest & 41,0 \\
\cline { 2 - 3 } & Vidéki nagyváros & 20,8 \\
\cline { 2 - 3 } & Vidéki kisváros, falu & 25,2 \\
\cline { 2 - 3 } & Külföld & 13,0 \\
\hline Családi állapot & Egyedülálló & 44,4 \\
\cline { 2 - 3 } & Párkapcsolatban & 55,6 \\
\hline \multirow{3}{*}{ végzettség } & Alapfokú & 3,5 \\
\cline { 2 - 3 } & Középfokú & 32,6 \\
\cline { 2 - 3 } & Felsófokú & 32,9 \\
\hline
\end{tabular}

\subsection{Mérőeszközök}

A vizsgálati személyek online kérdőíves felületen vettek részt a kutatásban. A demográfiai kérdések (nem, életkor, lakóhely, kapcsolati állapot, iskolai végzettség) megválaszolása után a résztvevők a flow-élményhez és jóllét koncepciókhoz kapcsolódó méróeszközöket töltöttek ki.

Általános Flow Leírás (ÁFL) (Magyaródi \& Oláh, 2015a). Az Általános Flow Index (General Flow Index) (Jackson \& Roberts, 1992) alapján alkottunk egy leírást az áramlat-élményről, amelyet elolvasva a vizsgálati személy értékeli egy-egy ötfokú Likert-típusú skálán (1: egyáltalán nem - 5: egészen nagymértékben), hogy mennyire jellemző rá az élmény a mindennapjai során, és mennyire intenzív általában az élmény. Jelen kutatásban kizárólag a gyakoriság skálát használtuk. A leírás segítségével azonosítható az a legjellemzőbb tevékenység is, amely során az élményt tapasztalja a személy.

Általános Flow Leírás Társas Interakciókban (ÁSZFL) (Magyaródi \& Oláh, 2015a). A válaszadó egy leírást olvashat a társas helyzetben átélhetó flowélményről, amely után értékeli egy-egy ötfokú Likert-típusú skálán (1: egyáltalán nem - 5: egészen nagymértékben), mennyire jellemző rá a közös élmény a mindennapjai során, és mennyire intenzív általában a közös élmény. Jelen vizsgálatban kizárólag a gyakorisági változót elemeztük. 
A leírást alkalmaztuk a vizsgálatban annak a közös, társas tevékenységnek az azonosítására, amelyben a vizsgálati személy a leggyakrabban éli át a flow-élményt.

Flow Állapot Kérdőív (Magyaródi, Nagy, Soltész, Mózes, \& Oláh, 2013). A Flow Állapot Kérdőív (FÂK) az áramlatélmény alapdimenzióit méri, 20 item segítségével. A résztvevők ötfokú Likert-típusú skálán értékelik az egyes állításokat (1: egyáltalán nem értek egyet - 5: teljesen egyetértek). A FÁK két alskálából áll: a Kihívás-készség-egyensúly skálából, amely a flow-zónába lépés alapvetó feltételeire utal, az Egybeolvadás az élménnyel skála pedig a flow kísérőjelenségeit foglalja össze. A skálák belső megbízhatósága megfelelő $\left(\alpha_{\mathrm{K}-\mathrm{K}}=0,92 ; \alpha_{\mathrm{E}}=0,91\right)$. A válaszadó a jelölt tevékenység során általában tapasztalt élményeiről számol be. A kérdőív jelen vizsgálatban a partnerrel közös tevékenység során tapasztalható áramlat-élményre vonatkozik.

Flow Szinkronizáció Kérdőív (Magyaródi \& Oláh, 2015b). A Flow Szinkronizáció Kérdőív (FSZK) 28 tételes kérdőív 5 skálán keresztül ragadja meg azokat a tényezőket, amelyek a közös interakciós flow-helyzetben az átélt élményt kísérik, támogatják. A skálák a következők: Hatékonyság és összehangoltság a partnerrel; Bevonódásélmény és koncentráció; Motiváció és pozitív hatás a partnerre; Motiváció és tanulás a személy számára; Koordináció a partnerrel a tevékenység közben. A válaszadók ötfokú Likert-típusú skálán (1: egyáltalán nem - 5: teljes mértékben) válaszolnak az egyes állításokra (pl. 19. Automatikusan együtt tudunk múködni a partneremmel.) A skálák belső megbízhatósága megfelelő $(0,80 \leq \alpha \leq 0,93)$. A vizsgálati személy a jelölt tevékenység során általában tapasztalt élményeiról számol be. A kérdőív jelen vizsgálatban a partnerrel közös tevékenység során tapasztalható flow-szinkronizációs összetevőkre vonatkozik.

Élettel Való Elégedettség Skála (Satisfaction with Life Scale, SWLS) (Diener és mtsai, 1985; Martos, Sallay, Désfalvi, Szabó, \& Ittzés, 2014). Az Élettel Való Elégedettség Skála egy 5-tételes, önbeszámolós kérdőív, amely az élettel való általános elégedettséget méri. A válaszadó az állításokat hétfokú Likert-típusú skálán (1: egyáltalán nem értek egyet - 7: teljes mértékben egyetértek) értékeli. A kérdőív magyar változatának reliabilitásmutatói különböző minták tesztelésekor is megfelelőnek mutatkoztak $(0,84<\alpha<0,90)$ (Martos és mtsai, 2014).

Pszichológiai Jóllét Skálák (Scales of Psychological Well-being, PWB) (Oláh, 2012; Ryff \& Keyes, 1995). A kérdőív 18 tételt tartalmaz, amelyek a pszichológiai jóllét hat dimenzióját mérik (önelfogadás, pozitív kapcsolat másokkal, autonómia, környezeti hatékonyság, életcél, személyes növekedés), megfelelve a pszichológiai jóllét elméleti és koncepcionális alapjainak. A vá- 
laszadás során a résztvevők minden állítást hatfokú Likert-típusú skálán értékelnek (1: teljesen egyetértek - 6: egyáltalán nem értek egyet). A Pszichológiai Jóllét Skálák reliabilitásmutatói a gyenge és mérsékelt értékek között mozogtak (önelfogadás: $\alpha=0,52$, környezeti hatékonyság: $\alpha=0,49$, pozitív kapcsolat másokkal: $\alpha=0,56$, életcél: $\alpha=0,33$, személyes növekedés: $\alpha=$ 0,40, autonómia: $\alpha=0,37$ ) (Ryff \& Keyes, 1995). A skálák magyar verziója szintén gyenge-mérsékelt reliabilitásértékeket mutat $(0,4<\alpha<0,6)$ (Oláh, 2012).

\subsection{Eljárás}

Az Eötvös Loránd Tudományegyetem Kutatásetikai Bizottsága támogatta a vizsgálat megvalósítását (Iktatási szám: 2014/13.). A résztvevő́k toborzása egyetemi kurzusokon és közösségi média felületeken történt. A részvétel feltételei a következők voltak: 18. életév betöltése, pszichiátriai és neurológiai problémáktól való mentesség. A kérdőív kitöltése online felületen történt, a tájékoztató elolvasása és vizsgálatba történő beleegyezés után 15-20 percet vett igénybe.

\subsection{Alkalmazott statisztikai próbák}

A kutatásban alkalmazott skálák belső konzisztenciájának becsléséhez Cronbach-a-mutatókat számítottunk. A leíró statisztikai vizsgálatok után a változók közötti kapcsolatvizsgálatot végeztük el Pearson-féle korrelációs módszerrel. A hipotézisteszteléshez mindkét hipotézis esetében hierarchikus lineáris regresszióelemzést alkalmazunk, Enter módszerrel léptetve be a független változókat a modellbe. Az elemzéseket SPSS Statistics 25 statisztikai programcsomaggal végeztük.

\section{Eredmények}

A vizsgálat során alkalmazott változók leíró statisztikai eredményeit és belső megbízhatóságának mutatóit a 2. táblázatban ismertetjük.

A Pszichológiai Jóllét Skálák belső konzisztencia mutatóinak alacsony értékei a mi vizsgálatunkban is problémaként merültek fel. Sok esetben kritizálták már a skálákat az alacsony belső megbízhatóságuk miatt, ennek ellenére a mérőeszköz használatban van (Fernandes, Vasconcelos-Raposo, \& Teixeira, 2010; van Dierendonck, Díaz, Rodríguez-Carvajal, Blanco, \& 
Moreno-Jiménez, 2008), mivel kialakítása során a meglévő tételek reprezentálták leginkább a dimenziók elméleti és konceptuális alapjait (Ryff \& Keyes, 1995). Mivel a PWB összesített skálaként megfelelő reliabilitásértéket mutatott, így elemzésünkben ezt a változót használtuk.

2. táblázat. Az elemzés során alkalmazott változók leíró statisztikája, reliabilitásmutatói

\begin{tabular}{|c|c|c|c|}
\hline Skála & $\mathbf{M}$ & SD & $\begin{array}{l}\text { Cronbach-a } \\
\text { (tételszám) }\end{array}$ \\
\hline Egyéni flow gyakoriság (ÁFL) & 3,49 & 0,86 & $\begin{array}{c}- \\
(1)\end{array}$ \\
\hline Társas flow gyakoriság (ÁSZFL) & 3,22 & 0,94 & $\begin{array}{c}- \\
(1)\end{array}$ \\
\hline Társas flow intenzitás (FÁK) & 3,62 & 0,40 & $\begin{array}{l}0,85 \\
(20)\end{array}$ \\
\hline Társas flow: szinkronitás (FSZK) & 3,95 & 0,58 & $\begin{array}{l}0,94 \\
(28)\end{array}$ \\
\hline Élettel való elégedettség (SWLS) & 4,72 & 10,24 & $\begin{array}{c}0,86 \\
(5)\end{array}$ \\
\hline Autonómia (PWB) & 4,18 & 0,97 & $\begin{array}{l}0,55 \\
(3)\end{array}$ \\
\hline Életcél (PWB) & 4,54 & 0,91 & $\begin{array}{c}0,36 \\
(3)\end{array}$ \\
\hline Környezeti hatékonyság (PWB) & 4,09 & 0,85 & $\begin{array}{l}0,48 \\
(3)\end{array}$ \\
\hline Önelfogadás (PWB) & 4,23 & 0,95 & $\begin{array}{c}0,64 \\
(3)\end{array}$ \\
\hline Pozitív kapcsolatok (PWB) & 3,95 & 0,88 & $\begin{array}{c}0,54 \\
(3)\end{array}$ \\
\hline Személyes növekedés (PWB) & 4,67 & 1,05 & $\begin{array}{l}0,65 \\
(3)\end{array}$ \\
\hline Pszichológiai jóllét (PWB) & 4,28 & 0,64 & $\begin{array}{l}0,85 \\
(18)\end{array}$ \\
\hline
\end{tabular}

A hipotézistesztelésben alkalmazandó változók közötti kapcsolatvizsgálathoz Pearson-féle korrelációs elemzést alkalmaztunk. A változók közötti kapcsolatok szignifikánsak, pozitív irányúak, és egy kivétellel gyenge, illetve közepes mértékúek (3. táblázat). 
3. táblázat. Az elemzés során alkalmazott változók közötti korreláció.

\begin{tabular}{|l|c|c|c|c|c|}
\hline \multicolumn{1}{|c|}{ Változók } & $\mathbf{1}$ & $\mathbf{2}$ & $\mathbf{3}$ & $\mathbf{4}$ & $\mathbf{5}$ \\
\hline Egyéni flow gyakoriság (ÁFL) & - & & & & \\
\hline Társas flow gyakoriság (ÁSZFL) & $0,42^{* *}$ & - & & & \\
\hline Társas flow intenzitás (FÁK) & $0,24^{* *}$ & $0,30^{* *}$ & - & & \\
\hline Társas flow: szinkronitás (FSZK) & $0,22^{* *}$ & $0,36^{* *}$ & $0,52^{* *}$ & - & \\
\hline Élettel való elégedettség (SWLS) & $0,11^{* *}$ & $0,14^{* *}$ & $0,13^{* *}$ & $0,13^{* *}$ & - \\
\hline Pszichológiai jóllét (PWB) & $0,14^{* *}$ & $0,10^{* *}$ & $0,10^{* *}$ & $0,17^{* *}$ & $0,42^{* *}$ \\
\hline
\end{tabular}

Megjegyzés: ** $\mathrm{p}<0,01$.

Az 1. hipotézis teszteléséhez hierarchikus lineáris regresszióanalízissel dolgoztunk (4. táblázat). Az elemzés során ellenőriztük, hogy az életkor kontrollja (1. modell) mellett az egyéni helyzetben tapasztalt flow-élmény gyakorisága (2. modell) és a társas helyzetben tapasztalt áramlat-élmény gyakorisága, intenzitása és szinkronizációs sajátosságai (3. modell) magyarázó tényezői-e az élettel való elégedettségnek. A multikollinearitás problémája a varianciainflációs tényezők alapján nem merült fel. Az 1. hipotézist az eredmények alátámasztják.

4. táblázat. Hierarchikus lineáris regresszióelemzés az élettel való elégedettség és flow kapcsolatának teszteléséhez.

\begin{tabular}{|c|c|c|c|c|c|c|c|}
\hline 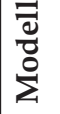 & Független változók & $\mathbf{R}^{2}$ & $F(d f)$ & p & $\beta$ & p & VIF \\
\hline 1. & Életkor & 0,01 & $\begin{array}{r}6,46 \\
(1,1058)\end{array}$ & 0,011 & $-0,08$ & 0,011 & 1,00 \\
\hline 2. & $\begin{array}{l}\text { Életkor } \\
\text { Egyéni flow gyakoriság (ÁFL) }\end{array}$ & 0,02 & $\begin{array}{r}10,13 \\
(2,1057)\end{array}$ & $<0,001$ & $\begin{array}{r}-0,08 \\
0,11\end{array}$ & $\begin{array}{r}0,009 \\
<0,001\end{array}$ & $\begin{array}{l}1,00 \\
1,00\end{array}$ \\
\hline 3. & $\begin{array}{l}\text { Életkor } \\
\text { Egyéni flow gyakoriság (ÁFL) } \\
\text { Társas flow gyakoriság (ÁSZFL) } \\
\text { Társas flow intenzitás (FÁK) } \\
\text { Társas flow szinkronitás (FSZK) }\end{array}$ & 0,04 & $\begin{array}{r}8,96 \\
(5,1054)\end{array}$ & $<0,001$ & $\begin{array}{r}-0,09 \\
0,05 \\
0,07 \\
0,08 \\
0,06\end{array}$ & $\begin{array}{l}0,003 \\
0,125 \\
0,038 \\
0,039 \\
0,093\end{array}$ & $\begin{array}{l}1,01 \\
1,24 \\
1,35 \\
1,44 \\
1,46\end{array}$ \\
\hline
\end{tabular}

Megjegyzés: Függő változó: élettel való elégedettség (SWLS), VIF = varianciainflációs tényezö. 
Az elemzés eredményei szerint a változók között szignifikáns lineáris kapcsolat van. A determinációs együttható értékei alapján elmondható, hogy a vizsgált mintán a társas helyzetben tapasztalt áramlat gyakorisága és intenzitása 2\%-kal több magyarázóerőt ad hozzá a regressziós modellhez az élettel való elégedettség vonatkozásában, mint a flow-élmény egyéni gyakorisága és az életkor együtt. A fentieken túl az egyéni flow-élmény gyakoriságának szignifikáns előrejelző értéke megszúnik a társas dimenziók modellbe léptetésével. Az életkor szignifikáns predikciós erővel bír, fordított irányú kapcsolatot mutat az élettel való elégedettséggel.

A 2. hipotézis teszteléséhez alkalmazott hierarchikus lineáris regresszióelemzés eredményei szerint (5. táblázat) a kizárólag az életkort tartalmazó regressziós modell nem szignifikáns, az életkornak nincs szignifikáns lineáris kapcsolata a pszichológiai jólléttel. Az egyéni flow gyakoriság önmagában magyarázhatja a pszichológiai jóllétet a 2. modell szerint, valamint a társas flow élmény szinkronizációs aspektusai további predikciós erővel bírnak a pszichológiai jóllétre vonatkozóan. A 2. hipotézis részben igazolódott, mivel kizárólag az egyéni flow gyakoriság és a szinkronizációs tényezők bizonyultak szignifikáns magyarázó tényezőknek a pszichológiai jóllét mértékére vonatkozóan, sem a társas flow gyakorisága, sem az intenzitása nincs szignifikáns kapcsolatban a függő változóval.

5. táblázat. Hierarchikus lineáris regresszióelemzés a pszichológiai jóllét és flow kapcsolatának teszteléséhez

\begin{tabular}{|c|c|c|c|c|c|c|c|}
\hline 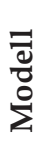 & Független változók & $\mathbf{R}^{2}$ & $F(d f)$ & p & $\beta$ & p & VIF \\
\hline 1. & Életkor & 0,00 & $\begin{array}{r}60,07 \\
(1,1058)\end{array}$ & 0,793 & $-0,01$ & 0,793 & 1,00 \\
\hline 2. & $\begin{array}{l}\text { Életkor } \\
\text { Egyéni flow gyakoriság (ÁFL) }\end{array}$ & 0,02 & $\begin{array}{r}9,98 \\
(2,1057)\end{array}$ & $<0,001$ & $\begin{array}{r}-0,01 \\
0,14\end{array}$ & $\begin{array}{r}0,724 \\
<0,001\end{array}$ & $\begin{array}{l}1,00 \\
1,00\end{array}$ \\
\hline 3. & $\begin{array}{l}\text { Életkor } \\
\text { Egyéni flow gyakoriság (ÁFL) } \\
\text { Társas flow gyakoriság (ÁSZFL) } \\
\text { Társas flow intenzitás (FÁK) } \\
\text { Társas flow: szinkronitás (FSZK) }\end{array}$ & 0,04 & $\begin{array}{r}8,74 \\
(5,1054)\end{array}$ & $<0,001$ & $\begin{array}{r}-0,02 \\
0,10 \\
0,01 \\
-0,01 \\
0,15\end{array}$ & $\begin{array}{r}0,633 \\
0,002 \\
0,976 \\
0,824 \\
<0,001\end{array}$ & $\begin{array}{l}1,01 \\
1,24 \\
1,35 \\
1,44 \\
1,46\end{array}$ \\
\hline
\end{tabular}

Megjegyzés. Függő változó: pszichológiai jóllét (PWB), VIF = varianciainflációs tényező. 


\section{Diszkusszió}

Keresztmetszeti kérdőíves kutatásunk célja az áramlat-élmény és jóllét öszszefüggéséről szóló eredmények kibővítése volt, a flow társas helyzetben való megtapasztalásának egyidejú vizsgálatával, amely újabb kutatási téma a pozitív pszichológiában.

Ugyan a flow-élmény átélésének gyakoriságai és különböző dimenzióinak intenzitása csak nagyon kis százalékban magyarázzák az élettel való elégedettség varianciáját, az eredmények támogatják a korábbi elképzeléseket az összefüggésekről (Csikszentmihalyi, 1993; Sahoo \& Sahu, 2009; Vittersø, 2003), továbbá az élmény társas helyzetben való átélésének feltételezett hatásával egészítik ki. Az élettel való elégedettség a szubjektív jóllét kognitív komponense, az interakciós helyzetben tapasztalt flow az emlékezet számára hozzáférhetőbb lehet a társas aspektus mint plusz környezeti információ miatt (Echterhoff \& Hirst, 2009), így a szubjektív beszámolókban is intenzívebb hatásúként jelenhet meg. Mivel a flow-élmény inkább a szubjektív jóllét érzelmi, semmint kognitív aspektusához köthető, így az alacsony, de szignifikáns predikciós erő illeszkedik a korábbi eredményekhez (Fritz \& Avsec, 2007). A kapcsolatot azonban szükséges tovább vizsgálni, a jelen kutatásban kapott kismértékú összefüggésmutatók miatt. A kismértékú összefüggés elfogadható lehet ugyan abban a tekintetben, hogy az élettel való elégedettséghez számos egyéb szempont, aktivitás hozzájárul: például a szabadság megélése (Wan \& Zhao, 2018), vagy akár a személyt körülvevő természeti, szociális, illetve kulturális tóke is (Kubiszewski, Zakariyya, \& Costanza, 2018).

Annak támogatásával, hogy az áramlat együttmúködő, közös tevékenységében is megtapasztalható legyen (pl. iskolában, munkatevékenységekben), a flow-élmény gyakorlásának lehetóségei kibővülnek, ezáltal hozzásegítve a személyt az áramlat-élmény minél gyakoribb átéléséhez (Magyaródi \& Oláh, 2015a). A szubjektív jóllét temporális elképzelése, az ún. 3P (Past, Present, Prospect) elmélet, amely a jelen, múlt és jövő idői állapotai alapján kategorizálja a szubjektív jóllét komponenseit (Durayappah, 2011), támogatja a kapott eredményt: a flow-élmény a jelen állapotai közé tartozik, amely magasabb élettel való elégedettséghez vezethet. Fontos eredmény, hogy fordított irányú kapcsolat mutatkozik a mintában az életkor és az élettel való elégedettség között, amelyet korábban idős mintát vizsgálva szintén kimutattak (Uma Devi, Kavithakiran, \& Swachita, 2015). Az életkor és az élettel való elégedettség közötti összefüggés vizsgálatához szintén további, az életkori különbségeket illetően szisztematikus kutatások szükségesek.

A flow és a mentális egészség kapcsolatáról számos hipotézis született, amelyek alapja az áramlat hozzájárulása az optimális múködéshez (Csikszentmihalyi \& Rathunde, 1993). Eredményeink szerint az egyéni 
helyzetben átélt flow-élmény gyakorisága és a partnerrel interakcióban érzett szinkronitás mértéke valóban kapcsolatban állnak a jól múködéssel, tehát a pszichológiai jóllét és flow összefüggéséhez alapvető információkat szolgáltat a jelenlegi kutatás. A pszichológiai jóllét összetettsége miatt a flow-aspektusok kismértékú magyarázó hatásai elfogadhatók. Az eddig csak hipotézisként megfogalmazott összefüggés az áramlat gyakorisága és a pszichológiai jóllét kapcsolatáról igazolást nyert (Chen és mtsai, 2000). A flow interakciós aspektusai (flow szinkronizáció) magasabb prediktív erejúnek túntek az egyéni flow gyakoriságnál. Ezt az eredményt támogatja, hogy a flow társas helyzetben való átélése intenzívebb az egyéni megtapasztalásnál, magasabb minőségú élményről lehet szó (Magyaródi \& Oláh, 2017), így a hozzáadott értéke is több lehet, vélhetően az interakcióból fakadó többlet miatt, összhangban a szinkronizációs elképzelésekkel (Ackerman \& Bargh, 2010; Magyaródi \& Oláh, 2015b). A flow társas helyzetben tapasztalt sajátosságai tehát kapcsolatban állnak a pszichológiai jólléttel (Ryff, 1989), alátámasztva ezzel Csikszentmihalyi alapvetéseit az áramlat fejlődéshez és mentális egészséghez való viszonyáról (Hektner \& Csikszentmihalyi, 1996). A flow-élmény a tiszta célok kitúzésén, kihívások keresésén keresztül (Csikszentmihalyi, 2009) járul hozzá az autonómia megvalósításához. A személy-környezet-interakció a környezeti hatékonyságot támogatja, mivel a személy képes kontroll alatt tartani a tevékenységeket, olyan lehetóségeket keresve, amelyek megfelelnek a saját készségeinek. A flow-élmény az emergens motiváción (Nakamura \& Csikszentmihalyi, 2002) keresztül a személyes növekedéshez járul hozzá: a személy a készségei szintjét folyamatosan hozzáilleszti a növekvő kihívásokhoz. A személyes növekedés a flow-élmény gyakori átélésével lehet összefüggésben, mivel a személy megtalálja azokat a helyzeteket, amelyek a fejlődéshez segítik hozzá. Az önelfogadás pedig az énhatékonyság-érzésen (Bandura, 1998) keresztül kapcsolódhat az áramlat átéléséhez, a kompetencia gyakorlásához a kihívást jelentő helyzetekben. A flow-élmény társas helyzetben minél gyakoribb és intenzívebb átélése a kapcsolatok fejlesztésére lehet pozitív hatással (Graham, 2008; Sawyer, 2008), így járulva hozzá a mentális egészség pozitív kapcsolat másokkal faktorához.

Kitekintésként említjük meg, hogy mentális egészség koncepcióként az ún. PERMA-modell ${ }^{1}$ (Seligman, 2011) a jól múködés, avagy pszichológiai jóllét integrált részeként tekinti a törekvést az áramlat-élmény átélésére.

\footnotetext{
1 A PERMA-modell (Seligman, 2011) kezdőbetúi a pozitív érzelmek (hedonisztikus élet) ( $P$ : Positive emotion), elkötelezódés (flow-élménnyel teli élet) ( $E$ : Engagement), pozitív kapcsolatok ( $R$ : Relationships), jelentésteliség (az élet céljának megtalálása, önmegvalósítása) (M: Meaning), és teljesítmény (cél felé haladás a mindennapi tevékenységekben, teljesítményérzés) (A: Accomplishments) faktorokat jelölik.
} 
Kutatásunkban ugyan nagy elemszámú mintával dolgoztunk, azonban a résztvevőket kényelmi, hólabda mintavétellel vontuk be, így az eredmények általánosíthatósága korlátozott. A fiatal felnőtt korosztály alkotta a minta nagy részét, továbbá az alacsony iskolai végzettségúek alulreprezentáltak voltak a mintában: ezen szempontokat fontos kiemelnünk a jólléthez kapcsolódó esetleges kulturális, demográfiai jellemzők menti különbségek miatt (Anić \& Tončić, 2013; Collins és mtsai, 2009; Delle Fave, Massimini, \& Bassi, 2011). Lényeges szempontként jelennek meg a visszatekintési torzítás problémái (Hassan, 2005), továbbá az élettel való elégedettség önbeszámolós méréseinek függósége az aktuális állapottól (Durayappah, 2011). A kutatás limitációi közé tartozik az önbeszámolós kérdőívek használatán túl a Pszichológiai Jóllét Kérdőív (Ryff, 1989) belső konzisztenciájának problematikussága. Ennek kiküszöböléséhez fontosnak tartjuk a jövőben egyéb, mentális egészséget vizsgáló mérőeszköz alkalmazását, pl. a Mentális Egészség Kontinuumot (Keyes, 2002; Reinhardt, 2013), amelynek egyik elméleti alapját képezi a pszichológiai jóllét koncepciója. Keresztmetszeti vizsgálattal dolgoztunk, holott feltételezéseink megalapozásához, az ok-okozati vagy cirkuláris összefüggések (Fredrickson, 1998) igazolásához szükség lehet egy longitudinális kutatásra. A hosszmetszeti kutatással a hétköznapi aktuális élmények és a jóllét dimenzióinak többszöri értékelésével a gyújtött adatok pontossága nőhet. Elképzelhetó továbbá, hogy a flow-élmény átélése és a jóllét különböző dimenziói tekintetében körkörös okságról beszélhetünk, mivel a flow-élmény nemcsak előrejelző tényezője lehet például a szubjektív jóllétnek (Fritz \& Avsec, 2007), hanem a magasabb jóllét-szinttel rendelkező személyek intenzívebb flow-élményt is tapasztalnak (Sahoo \& Sahu, 2009). A jövőben fontosnak tartjuk a jóllét egyéb dimenzióinak elemzését is: például a szubjektív jóllét érzelmi komponensét, a pozitív és negatív érzelmek arányának vizsgálatával (Fritz \& Avsec, 2007). Amennyiben a flow-élmény átélésének vizsgálatát a diádikus szinten túlra ki tudjuk terjeszteni, úgy több személy bevonásával, a személy csoporthoz, társadalomhoz tartozásával a szociális jóllét dimenziói is vizsgálhatóvá válnak (Keyes, 1998).

Lyubomirsky szubjektív jóllétre vonatkozó boldogság modelljében (Lyubomirsky, Sheldon, \& Schkade, 2005) hangsúlyozza, hogy a személy jólléte 50\%-ban biológiai alapokkal rendelkezik, 10\%-ban függ az életkörülményektől, és $40 \%$ jelenti azokat a tudatos tevekénységeket, amelyek az aktuális boldogságérzés fokozásáért felelőssé tehetők: ezt a pozitív érzelmek magas szintje jelzi (Lyubomirsky, King, \& Diener, 2005). A boldogságfokozó gyakorlatok (Lyubomirsky, 2008) között szerepel a flow minél gyakoribb átélése, amelynek társas helyzetben való megtapasztalása akár intenzívebb hatással is lehet a hétköznapok szubjektív megítélésére vonatkozóan, továbbá a változatosság támogatásával fenntarthatóvá válik a megemelt boldogságszint, ezért fontosnak tartjuk a jövőben a flow-élmény intervenciós lehetőségeinek vizsgálatát, és megélésének támogatását a társas interakciókban. 


\section{Irodalom}

Ackerman, M., \& Bargh, J.A. (2010). Two to tango: Automatic social coordination and the role of felt effort. In B. Bruya (Ed.), Effortless attention - A new perspective in the cognitive science of attention and action (pp. 335-371). Cambridge, MA: The MIT Press

Anić, P., \& Tončić, M. (2013). Orientations to Happiness, Subjective Well-being and Life Goals. Psihologijske Teme, 22(1), 135-153.

Bakker, A.B. (2005). Flow among music teachers and their students: The crossover of peak experiences. Journal of Vocational Behavior, 66(1), 26-44.

Bandura, A. (1998). Personal and Collective Efficacy in Human Adaptation and Change. In J.G. Adair, D. Bélanger, \& K.L. Dion (Eds.), Advances in Psychological Science: Vol 1: Personal, Social, and Cultural Aspects (1st ed., pp. 51-71). Hove: Psychology Press

Bryant, F.B., \& Veroff, J. (2006). Types of savoring: An integrative conceptual view. In F.B. Bryant \& J. Veroff (Eds.), Savoring: A new model of positive experience (pp. 112-143). Mahwah, NJ: Lawrence Erlbaum Associates

Carpentier, J., Mageau, G.A., \& Vallerand, R.J. (2012). Ruminations and flow: Why do people with a more harmonious passion experience higher well-being? Journal of Happiness Studies, 13(3), 501-518.

Chen, H., Wigand, R.T., \& Nilan, M. (2000). Exploring Web users' optimal flow experiences. Information Technology \& People, 13(4), 263-281.

Collins, A.L., Sarkisian, N., \& Winner, E. (2009). Flow and happiness in later life: An investigation into the role of daily and weekly flow experiences. Journal of Happiness Studies, 10(6), 703-719.

Csikszentmihalyi, M. (1975). Beyond Boredom and Anxiety. San Francisco: Jossey-Bass Publishers

Csikszentmihalyi, M. (1993). The evolving self: A psychology for the third millenium. New York: HarperCollins Publishers, Inc.

Csikszentmihalyi, M. (1997). Finding flow: The psychology of engagement with everyday life. New York: Basic Books.

Csikszentmihalyi, M. (1999). If we are so rich, why aren't we happy? American Psychologist, 54(10), 821-827.

Csikszentmihalyi, M. (2009). The Promise of Positive Psychology. Psihologijske Teme, 18(2), 203-211.

Csikszentmihalyi, M., \& Rathunde, K. (1993). The measurement of flow in everyday life: towards a theory of emergent motivation. In J.E. Jacobs (Ed.), Nebraska Symposium on Motivation, Vol.40: Developmental Perspectives on Motivation (pp.57-98). Lincoln: University of Nebraska Press

Delle Fave, A., Massimini, F., \& Bassi, M. (Eds.) (2011). Psychological selection and optimal experience across cultures. Social empowerment through personal growth. New York: Springer

Diener, E. (1984). Subjective well-being. Pyschological Bulletin, 95(3), 542-575.

Diener, E., Emmons, R.A., Larsen, R.J., \& Griffin, S. (1985). The Satisfaction With Life Scale. Journal of Personality Assessment, 49(1), 71-75.

Diener, E., Lucas, R.E., \& Oishi, S. (2011). Subjective well-being: The science of happiness and life satisfaction. In S.J. Lopez \& C.R. Snyder (Eds.), The Oxford handbook of positive psychology (2nd ed., pp. 187-194). New York: Oxford University Press

Durayappah, A. (2011). The 3P model: A general theory of subjective well-being. Journal of Happiness Studies, 12(4), 681-716.

Echterhoff, G., \& Hirst, W. (2009). Social influence on memory. Social Psychology, 40(3), 106-110. 
Engeser, S., \& Schiepe-Tiska, A. (2012). Historical Lines and Overview of Current Research on Flow. In S. Engeser (Ed.), Advances in Flow Research (pp. 1-22). New York: Oxford University Press

Fernandes, H.M., Vasconcelos-Raposo, J., \& Teixeira, C.M. (2010). Preliminary analysis of the psychometric properties of Ryff's Scales of Psychological Well-being in Portuguese adolescents. The Spanish Journal of Psychology, 13(2), 1032-1043.

Fredrickson, B.L. (1998). What good are positive emotions? Review of General Psychology, 2(3), 300-319.

Fredrickson, B.L., \& Losada, M.F. (2005). Positive affect and the complex dynamic of human flourishing. American Psychologist, 60(7), 678-686.

Fritz, B. S., \& Avsec, A. (2007). The experience of flow and subjective well-being of music students. Horizons of Psychology, 16(2), 5-17.

Graham, J.M. (2008). Self-expansion and flow in couples' momentary experiences: An experience sampling study. Journal of Personality and Social Psychology, 95(3), 679-694.

Harker, L., \& Keltner, D. (2001). Expressions of positive emotion in women's college yearbook pictures and their relationship to personality and life outcomes across adulthood. Journal of Personality and Social Psychology, 80(1), 112-124.

Hassan, E.S. (2005). Recall bias can be a threat to retrospective and prospective research designs. Internet Journal of Epidemiology, 3(2), 1-7. Letöltve: 2019. 04. 14-én: http:/ / ispub. com/IJE/3/2/13060

Hatfield, E., Cacioppo, J.T., \& Rapson, R.L. (1994). Emotional Contagion. Current Directions in Psychological Science, 2(3), 96-99.

Hektner, J.M., \& Csikszentmihalyi, M. (1996). A longitudinal exploration of flow and intrinsic motivation in adolescents. Paper presented at Annual Meeting of the American Educational Research Association, New York, April 8-12, 1996. Letöltve: 2019. november 10-én: https:/ / files.eric.ed.gov/fulltext/ED395261.pdf

Jackson, S.A., \& Roberts, G.C. (1992). Positive performance states of athletes: Toward a conceptual understanding of peak performance. The Sport Psychologist, 6, 156-171.

Jahoda, M. (1958). Current concepts of positive mental health. New York: Basic Books

Kashdan, T.B., \& Steger, M.F. (2011). Challenges, pitfalls, and aspirations for positive psychology. In K.M. Sheldon, T.B. Kashdan, \& M.F. Steger (Eds.), Designing positive psychology: Taking stock and moving forward (pp. 9-21). New York: Oxford University Press

Keller, J., \& Landhäußer, A. (2012). The flow model revisited. In S. Engeser (Ed.), Advances in flow research (pp. 51-64). New York: Springer

Keyes, C.L.M. (1998). Social wellbeing. Social Psychology Quarterly, 61(2), 121-140.

Keyes, C.L.M. (2002). The mental health continuum: From languishing to flourishing in life. Journal of Health and Social Research, 43(2), 207-222.

Kubiszewski, I., Zakariyya, N., \& Costanza, R. (2018). Objective and subjective indicators of life satisfaction in Australia: How well do people perceive what supports a good life? Ecological Economics, 154, 361-372.

Lakey, B. (2013). Perceived social support and happiness: The role of personality and relational processes. In I. Boniwell, S.A. David, \& A. Conley Ayers (Eds.), Oxford handbook of happiness (pp. 847-859). Oxford: Oxford University Press

Linley, A.P., Joseph, S., Harrington, S., \& Wood, A.M. (2006). Positive psychology: Past, present, and (possible) future, 1(1), 3-16. Doi: 10.1080/17439760500372796

Lyubomirsky, S. (2008). Hogyan legyünk boldogok? Életünk átalakításának útjai tudományos megközelítésben. Budapest: Ursus Libris Kiadó 
Lyubomirsky, S., King, L., \& Diener, E. (2005). The benefits of frequent positive affect: Does happiness lead to success? Psychological Bulletin, 131(6), 803-855.

Lyubomirsky, S., Sheldon, K.M., \& Schkade, D. (2005). Pursuing Happiness: The Architecture of Sustainable Change. Review of General Psychology, 9(2), 111-131.

Magyaródi, T., Nagy, H., Soltész, P., Mózes, T., \& Oláh, A. (2013). Egy újonnan kidolgozott Flow Állapot Kérdőív kimunkálásának és pszichometriai jellemzőinek bemutatása. Pszichológia, 33(1), 15-36.

Magyaródi, T., \& Oláh, A. (2015a). A cross-sectional survey study about the most common solitary and social flow activities to extend the concept of optimal experience. Europe's Journal of Psychology, 11(4), 632-650.

Magyaródi, T., \& Oláh, A. (2015b). Flow Szinkronizáció Kérdőív: az optimális élmény mechanizmusának mérése társas interakciós helyzetekben. Mentálhigiénéés Pszichoszomatika, 16(3), 271-296.

Magyaródi, T., \& Oláh, A. (2016). A Flow Szinkronizáció Kérdőív pszichometriai jellemzői: reliabilitás- és validitásvizsgálat. Mentálhigiéné és Pszichoszomatika, 17(2), 145-166.

Magyaródi, T., \& Oláh, A. (2017). The effect of social interaction on flow experience. International Journal of Psychology and Behavior Analysis Open Access, 3(126), 1-5. Doi: $10.15344 / 2455-3867 / 2017 / 126$

Martos, T., Sallay, V., Désfalvi, J., Szabó, T., \& Ittzés, A. (2014). Az Élettel való Elégedettség Skála magyar változatának (SWLS-H) pszichometriai jellemzői. Mentálhigiéné és Pszichoszomatika, 15(3), 289-303.

Maslow, A.H. (1954). Motivation and personality. New York: Harper \& Row Publishers, Inc.

Mózes, T., Magyaródi, T., Soltész, P., Nagy, H., \& Oláh, A. (2012). A flow-élmény operacionalizálásának útjai. Magyar Pszichológiai Szemle, 67(1), 57-76.

Nakamura, J., \& Csikszentmihalyi, M. (2002). The concept of flow. In C.R. Snyder \& S.J. Lopez (Eds.), Handbook of positive psychology (pp. 89-105). New York: Oxford University Press

Oláh, A. (2012). A megküzdés szivárványszínei: a stresszkezeléstől a boldogság növeléséig. In M. Fülöp \& É. Szabó (Eds.), A pszichológia mint társadalomtudomány - A 70 éves Hunyady György tiszteletére (pp. 507-522). Budapest: Eötvös Kiadó

Peterson, C., Park, N., \& Seligman, M.E.P. (2005). Orientations to happiness and life satisfaction: The full life versus the empty life. Journal of Happiness Studies, 6(1), 25-41.

Reinhardt, M. (2013). Mentális egészség és tünetképzés összefüggései a családi müködéssel serdülőknél. PhD értekezés. Budapest: Eötvös Loránd Tudományegyetem.

Ryan, R.M., \& Deci, E.L. (2000). Self-determination theory and the facilitation of intrinsic motivation, social development, and well-being. American Psychologist, 55(1), 68-78.

Ryff, C.D. (1989). Happiness is everything, or is it? Explorations on the meaning of psychological well-being. Journal of Personality and Social Psychology, 57(6), 1069-1081.

Ryff, C.D., \& Keyes, C.L.M. (1995). The structure of psychological well-being revisited. Journal of Personality and Social Psychology, 69(4), 719-727.

Sahoo, F.M., \& Sahu, R. (2009). The role of flow experience in human happiness. Journal of the Indian Academy of Applied Psychology, 35(spec iss), 40-47.

Sawyer, K. (2008). Group genius: The creative power of collaboration. New York: Basic Books

Seligman, M.E.P. (2011). Flourish: A visionary new understanding of happiness and well-being. New York: Free Press

Seligman, M.E.P., \& Csikszentmihalyi, M. (2000). Positive psychology - An introduction. American Psychologist, 55(1), 5-14. 
Snyder, C.R., \& Lopez, S.J. (2010). Interceding to prevent the bad and enhance the good. In C.R. Snyder \& S.J. Lopez (Eds.), Positive psychology: The scientific and practical explorations of human strengths (pp. 347-376). Thousand Oaks, CA: Sage Publications, Inc.

Uma Devi, L., Kavithakiran, V., \& Swachita, P. (2015). Satisfaction with life in elderly with reference to gender, age and residence. IOSR Journal Of Humanities And Social Science, 20(4), 57-59.

van Dierendonck, D., Díaz, D., Rodríguez-Carvajal, R., Blanco, A., \& Moreno-Jiménez, B. (2008). Ryff's six-factor model of psychological well-being, A Spanish exploration. Social Indicators Research, 87(3), 473-479.

Vittersø, J. (2003). Flow versus life satisfaction: A projective use of cartoons to illustrate the difference between the evaluation approach and the intrinsic motivation. Journal of Happiness Studies, 4, 141-167.

Walker, C.J. (2010). Experiencing Flow: is doing it together better than doing it alone? The Journal of Positive Psychology, 5(1), 3-11. Doi: 10.1080/17439760903271116

Wan, S.K., \& Zhao, L. (2018). Assessing the role of components of life satisfaction. Applied Economics, 50(44), 4763-4773.

Westman, M. (2013). Crossover of positive states and experiences. Stress and Health, 29, 263-265.

\title{
Szerzói munkamegosztás
}

Magyaródi Tímea: elméleti és kutatási koncepció megalkotása, kutatástervezés, kézirat megszövegezése, statisztikai elemzések, eredmények értelmezése. Prof. Oláh Attila: a kutatás megtervezéséhez szükséges elméleti koncepció kidolgozása, mérőeszköz-választás, a kutatás szupervíziója, a kézirat ellenőrzése és véleményezése.

\section{Nyilatkozat érdekütközésról}

A szerzők ezúton kijelentik, hogy esetükben nem állnak fenn érdekütközések.

\section{Experiencing flow in social activities and its relationship with satisfaction with life and psychological wellbeing, in the sample of young adults}

\author{
MAGYARÓDI, TÍMEA - OLÁH, ATTILA
}

Theoretical background: Flow can contribute to well-being, because as an activity theory, it is related to the positive consequences, and contributions to development of the behavior. Aim: Flow in a social interaction and its relationship with the different well-being concepts has not been studied yet, however the contributing role of social relationships to well-being has been emphasized a lot. This study aims to reveal this relationship. We investigate the effect of the frequency and intensity of flow in social activities, and flow synchronization. Methods: 1060 adult people took part in the online cross-sectional survey study - age: $M(\mathrm{SD})$ $=26.67(10.76)$ years. They filled in the questionnaires anonymously: General Flow 
Description, General Flow Description in Social Interactions, Flow State Questionnaire, Flow Synchronization Questionnaire, Satisfaction with Life Scale, Scales of Psychological Well-being. Results: according to the hierarchical regression analysis, the frequency $(\beta=$ $0.07, p=0.038)$ and intensity $(\beta=0.08, p=0.039)$ of flow in a social activity can predict satisfaction with life, while the frequency of flow in solitary situations $(\beta=0.10, p=0.002)$ and flow synchronization (interactional aspects during a cooperative flow-inducing activity) $(\beta=0.15, p<0.001)$ may contribute to psychological well-being Consequences: the social aspects of flow can contribute to well-being, the frequency, intensity and synchronization factors can help elaborating the person's mental health.

Keywords: flow, flow synchronization, social, interaction, psychological well-being, satisfaction with life

A cikk a Creative Commons Attribution 4.0 International License (https:/ / creativecommons.org/ licenses/by/4.0/) feltételei szerint publikált Open Access közlemény, melynek szellemében a cikk bármilyen médiumban szabadon felhasználható, megosztható és újraközölhető, feltéve, hogy az eredeti szerző és a közlés helye, illetve a CC License linkje és az esetlegesen végrehajtott módosítások feltüntetésre kerülnek. (SID_1) 